\title{
Japanese Spiders of the Genus Ordgarius (Araneae: Araneidae)
}

\author{
Akio TANIKAWA ${ }^{1)}$
}

谷川明男 ${ }^{1)}$ : 日本産イセキグモ属のクモ類

\begin{abstract}
The Japanese spiders of the genus Ordgarius are revised. The males of Ordgarius hobsoni (O. PICKARD-CAMBridge, 1877) and O. sexspinosus (THORELL, 1894) are described for the first time based on the specimens collected from Kanagawa Pref., Japan.
\end{abstract}

Up to the present, two species of the spider genus Ordgarius have been recorded from Japan, that is, Ordgarius hobsoni (O. PICKARD-CAMBRIDGE, 1877) (KISHIDA, 1933; YAGINUMA, 1941, 1960, 1986; MATSUMOTO et al., 1976; SHINKAI \& TAKANO, 1984) and Ordgarius sexspinosus (THORELL, 1894) (YAGINUMA, 1960, 1986; MATSUMOTO et al., 1976; SHINKAI \& TAKANO, 1984; CHIKUNI, 1989). Both species are known as the bolas spiders (Figs. 2,4; SHINKAI, 1981; SHINKAI \& TAKANO, 1984; YAGINUMA, 1986).

Ordgarius hobsoni was described from India and Ceylon (=Sri Lanka). PICKARD-CAMBRIDGE (1877) described the species under the genus Cyrtarachne. Then SIMON (1894) transferred the species to the genus Ordgarius. The species has been known from India (P.-CAMBRIDGE, 1877; POCOCK, 1900; TIKADER, 1982), Sri Lanka (P. -CAMBridge, 1877; PoCOCK, 1900; TIKADER, 1982), China (WANG, ZHANG \& LI, 1985) and Japan (literature see above).

Ordgarius sexspinosus was originally described under the genus Notocentria based on the holotype from Tharawaddy, Burma (=Myanmar). Then SIMON (1894) synonymized Notocentria with Ordgarius. The species has been known from Burma (=Myanmar; THORELL, 1894, 1895, 1898; POCOCK, 1900), Indonesia (REIMOSER, 1927; WORKMAN, 1896), India (TIKADER, 1982) and Japan (literature see above).

The males of these species have not been described up to the present. Recently I obtained the male specimens of both the species collected from Kanagawa Pref., Japan. They will be described in this paper.

I wish to express my hearty thanks to Dr. Hirotsugu ONO, Department of Zoology, National Science Museum, Tokyo (NSMT), for his constant guidance and revising the manuscript of this paper. For loaning invaluable specimens, I am deeply indebted to Dr. Paul HILly ARD, The Natural History Museum, London (BM). My sincere thanks are also due to Mr. Ken-ichi KumADA, Miyagi, Mr. Akira SHINKAI, Tokyo, Mr. Ei-ichi SHINKAI, Tokyo, Mr. Mitsuru BAN, Kanagawa, Mr. Mamoru YAMAKAWA, Kanagawa, and Mr. Miyoshi SADAMOTO, Chiba, for their offering valuable specimens used in the

1) Shichirigahama Senior High School, 2-3-1, Shichirigahama-higashi, Kamakura-shi, Kanagawa, 248 Japan

神奈川県立七里ガ浜高等学校 テ 248 神奈川県鎌倉市七里ガ浜東 2-3-1

Accepted September 24, 1997 
present study.

\section{Genus Ordgarius}

Cyrtarachne (partim): O. PICKARD-CAMBRIDGE, 1877, p. 562.

Ordgarius KeYSERLING, 1886, p. 114. Type species Ordgarius monstrosus KeYSERLING, 1886, from Australia. - SIMON, 1895, p. 885. - PoCOCK, 1900, p. 230. - YAGINUMA, 1960, p. 63; 1986, p. 112.

Notocentria THORELL, 1894, p. 48.

Dicrostichus SIMON, 1894, p. 886.

Caerostris (partim): WORKMAN, 1896, p. 26.

Diagnosis. Spiders of the genus Ordgarius seem to be closely related to those of the genus Mastophora, in general appearance, feature of copulatory organs, hunting method, and sexual dimorphism. The most remarkable difference is the relative length of legs. The first legs of Ordgarius spiders are almost as long as second legs (Tables 1-2), but the first legs of Mastophora spiders are apparently longer than second legs (GERTSCH, 1955). This difference appears to be related to their hunting position. Ordgarius spiders hold the bolas lines with one of their second legs (Figs. 2, 4; SHINKAI, 1981; SHINKAI \& TAKANO, 1984), while Mastophora spiders hold them with one of their first legs (GERTSCH, 1955; STOWE, 1986). The shapes of the tubercles on carapaces of the two genera are also different (Figs.11, 18; GERTSCH, 1955).

Description. Female. Carapace slightly longer than wide, with tubercles in various shapes. Median ocular area wider than long; median eyes situated on a tubercle as well as lateral eyes. Labium wider than long. Sternum slightly longer than wide. Legs of adult females without spines other than a row of weak spines on prolateral side of metatarsi and tibiae of first and second legs. Abdomen wider than long; with various shaped tubercles. Epigynum simple.

Male. Much smaller than female. Carapace longer than wide; with tubercles in various shapes. Median ocular area wider than long. Labium wider than long. Sternum almost as long as wide. Metatarsi and tibiae of first and second legs prolaterally with a row of spines. Palpal patella without macroseta. Abdomen wider than long; with shoulder swelling. regions.

Species. Nine species have been known from Oriental, Palaearctic and Australian

Remarks. Most males of the Ordgarius spiders have been unknown. Males have been described in only two Australian species, $O$. monstrosus KEYSERLING, 1886 and $O$. magnificus (RAINBOW, 1897). In the present paper, the males of Ordgarius hobsoni (O. PICKARD-CAMBRIDGE, 1877) and Ordgarius sexspinosus (THORELL, 1894) will be described for the first time.

Key to the Japanese species

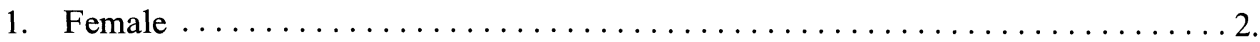

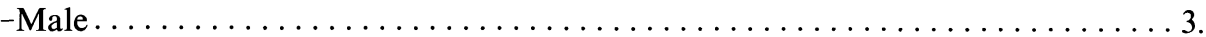

2. Abdomen dark brown, with many rounded reddish brown tubercles (Fig.1) ..... $\ldots \ldots \ldots \ldots \ldots \ldots \ldots \ldots \ldots \ldots \ldots$ O. hobsoni (O. PICKARD-CAMBridge, 1877). 

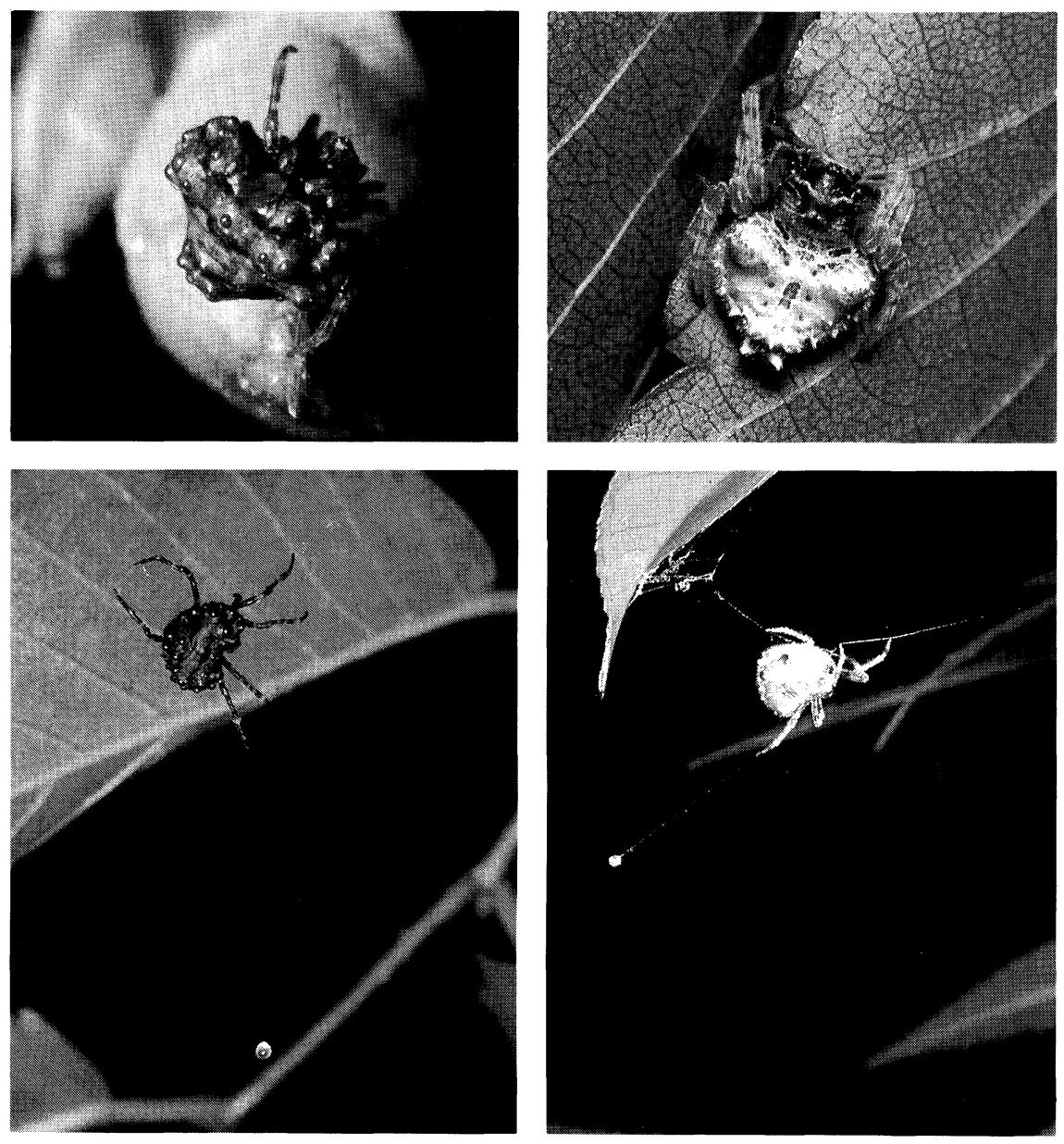

Figs. 1-4. 1 (Top, left). Ordgarius hobsoni (O. PICKARD-CAMBRIDGE, 1877), a female in resting position. 2 (Bottom, left). Same, with a bolas line. 3 (Top, right). Ordgarius sexspinosus (THORELL, 1894), a female in resting position. 4 (Bottom, right). Same, with a bolas line. (Photos: E. SHINKAI.)

-Abdomen pale brown with dark brown markings, with rounded shoulder humps, and with two pairs of cones at the posterior end (Fig. 3) ................. .................................... sexspinosus (THORELL, 1894).

3. Ventral side of abdomen uniformly blackish brown. Embolus rostriform (Fig.7). Tubercles of carapace as in Fig. 10 O. hobsoni (O. PICKARD-CAMBRIDGE, 1877). -Abdomen ventrally with a pair of white spots. Embolus spiniform (Fig. 13). Tubercles of carapace as in Fig. $17 \ldots \ldots \ldots$. . . sexspinosus (THORELL, 1894). 
Ordgarius hobsoni (O. PICKARD-CAMBRIDGE, 1877)

(Figs. 1-2, 5-11, 19)

Cyrtarachne hobsoni O. PICKARD-CAMBRIDGE, 1877, p. 562 (syntypes from India and Sri Lanka (= Ceylon), preserved in BM, one female from Sri Lanka examined).

Ordgarius hobsoni: SIMON, 1895, p. 885. - POCOCK, 1900, p. 230.—TIKADER, 1982, p. 137, figs. 256 -257. - KISHIDA, 1933, p. 30.-YAGINUMA, 1941, p. 120; 1960, p. 63, pl. 27, fig. 155; 1986, p. 112, pl. 29, fig. 3. - ROEWER, 1942, p. 902.—-BONNET, 1955, p. 3201. —-MATSUMOTO et al., 1976, p. 69, fig. 3. - SHINKAI \& TAKANO, 1984, p. 98. - WANG et al., 1985, p. 66. PLATNICK, 1989, p. 354.

Specimens examined. Syntype: 1 우, Punduloya, Sri Lanka, E.E.GrEEN leg. (BM1895.11.14.19; one of the syntypes).

Japanese specimens. 2 egg sacs, 5 juv., Jinmuji, Zushi-shi, Kanagawa Pref., 21-IX -1980 (egg sac), 31-IX-1980 (emergence), A. TANIKAWA leg.; 1 우, Aonohara, Tsukuigun, Kanagawa Pref., 15-IX-1996, M. YAMAKAwA leg. (NSMT-Ar 3530); 1 우, Okura, Hadano-shi, Kanagawa Pref., 27-VIII-1975, M. YAMAKAWA leg. (NSMT-Ar 3531); 1 ऽ. Mt. Kobo-yama, Hadano-shi, Kanagawa Pref., 25-VIII-1981, M. YAMAKAwa leg. (NSMT-Ar 3532); 1 ऽ, Oiso-cho, Naka-gun, Kanagawa Pref., 12-VIII-1989, K. KUMADA leg. (NSMT-Ar 3533); 1 우, Mt. Iwawaki-san, Osaka Pref., 20-VIII-1954, T. YAGINUMA leg. (NSMT-Ar 327).

Description (based on the Japanese specimens). Measurement (in $\mathrm{mm}$ ). Total length, 우 5.60-6.58, o $\sigma^{7}$ 1.78-1.80; carapace length 우 2.20-2.97, 자 0.84-0.92; width 우 2.00-2.73, 자 0.72-0.77; abdomen length 우 4.27-4.54, 지 0.92-0.99, width 우 5.80-6.40, 구 1.18-1.19. Length of legs of 1 우 1 가 from Kanagawa Pref. (NSMT-Ar 3531, 3532) as shown in Table 1.

Female. Carapace length/width 1.09-1.22; with one small and one large conical tubercle on midline and four small tubercles at the posterior end of cephalic region, both sides of cephalic part with one or two more small tubercles respectively (Fig. 11). Median ocular area length/width 0.77, anterior width/posterior width 0.91-0.97; median eyes situated on a gentle rise as well as lateral eyes (Fig. 11). Chelicera with three promarginal and one retromarginal teeth. Labium length/width 0.54-0.75. Sternum length/width 1.05-1.12. Length of leg I/length of carapace 2.87-3.03; metatarsi and tibiae of first and second legs prolaterally with a row of weak spines. Abdomen length/ width 0.67-0.75; with many rounded tubercles (Fig. 1). Female genitalia as in Figs. 89. Egg sac dark brown, with many points (Fig. 19).

Male. Carapace length/width 1.17-1.20; with four small tubercles at the posterior end of cephalic region (Fig. 10). Median ocular area length/width $0.80-0.85$, anterior width/posterior width $0.94-0.97$. Chelicera with three promarginal and one retromarginal teeth. Labium length/width 0.73-0.80. Sternum length/width 0.93-1.04. Length of leg I/length of carapace 2.78-3.06; metatarsi and tibiae of first and second legs prolaterally with a row of spines (Fig. 6). Male palp (Fig. 7): embolus rostriform; conductor and terminal apophysis weekly sclerotized; median apophysis well sclerotized; patella without macroseta. Abdomen length/width 0.79-0.83; with shoulder swelling (Fig. 5).

Coloration and markings in alcohol. Female. Carapace dark brown. Abdomen brown, tubercles reddish brown. 

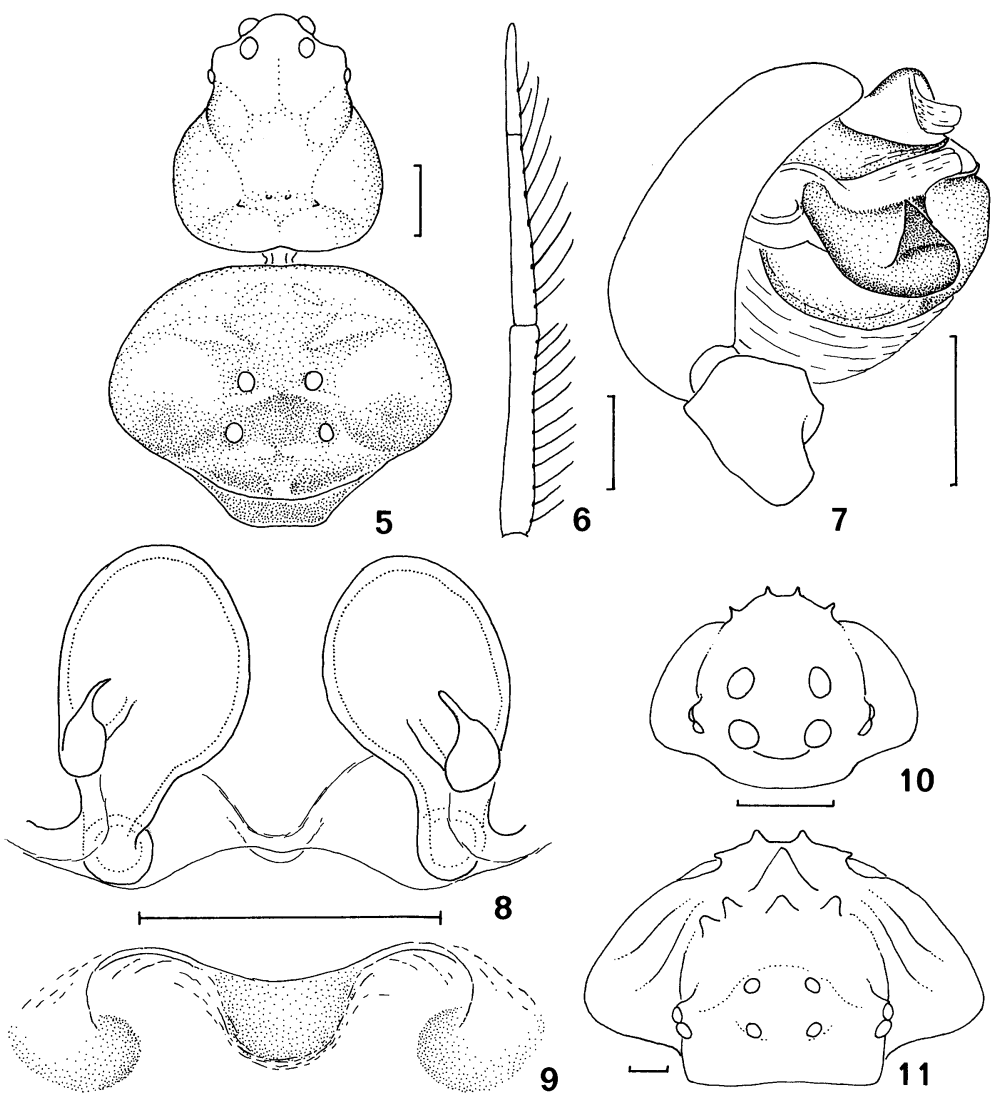

Figs. 5-11. Ordgarius hobsoni (O. PICKARD-CAMBRIDGE, 1877) (Female: NSMT-Ar 3531; male: NSMT-Ar 3532.) — 5. Male cephalothorax and abdomen, dosal view. 6. Left leg I of male, dorsal view. 7. Male left palp, mesal view. 8. Female genitalia, dorsal view. 9. Epigynum, ventral view. 10. Male cephalothorax, frontal view. 11. Female cephalothorax, frontal view. (Scales: $0.25 \mathrm{~mm}$.)

Male. Carapace dark brown. Abdomen dark brown mottled with black and pale brown; ventrally without marking.

Range. Japan, China, Sri Lanka, India.

Remarks. The Japanese female specimens agree exactly with the female syntype from Sri Lanka in every feature with the exception of their size. The syntype (total

Table 1. Measurement of leg segments of Ordgarius hobsoni (O. PICKARD-CAMBRIDGE, 1877) (in $\mathrm{mm}$; 우/ $\mathrm{o}^{7}$ ).

\begin{tabular}{ccccccc}
\hline Leg & Tarsus & Metatarsus & Tibia & Patella & Femur & Total \\
\hline I & $0.69 / 0.35$ & $2.03 / 0.51$ & $2.03 / 0.61$ & $1.14 / 0.32$ & $2.69 / 0.78$ & $8.58 / 2.57$ \\
II & $0.69 / 0.34$ & $2.04 / 0.46$ & $1.97 / 0.50$ & $1.16 / 0.31$ & $2.61 / 0.70$ & $8.47 / 2.31$ \\
III & $0.49 / 0.26$ & $0.97 / 0.21$ & $1.14 / 0.25$ & $0.86 / 0.20$ & $1.71 / 0.46$ & $5.17 / 1.38$ \\
IV & $0.46 / 0.23$ & $1.37 / 0.24$ & $1.76 / 0.38$ & $0.84 / 0.23$ & $2.49 / 0.56$ & $6.92 / 1.64$ \\
\hline
\end{tabular}


length $11.25 \mathrm{~mm})$ is much larger than the Japanese specimens $(5.60-6.58 \mathrm{~mm})$.

Though the feature of female abdomen (with many rounded tubercles) of the present species is unique in the genus, the structures of epigynum and internal genitalia are very similar to those of the other congeners. The present species has conspicuous terminal apophysis of male palp as $O$. sexspinosus. The males of two Australian species do not have terminal apophysis, or the apophysis are not visible (cf. DAVIES, 1988, figs. 36-37.). Judging from these points, the present species appears to be closer to $O$. sexspinosus than Australian species.

\section{Ordgarius sexspinosus (THORELL, 1894)}

(Figs. 3-4, 12-18, 20)

Notocentria sexspinosus THORELL, 1894, p. 48, 1895, p. 200 (young female holotype from Tharawaddy, Burma (=Myanmar), preserved in BM, examined).

Ordgarius sexspinosus: SIMON, 1895, p.885. —-THORELL, 1898, p. 369. - POCOCK, 1900, p. 230. -

-REIMOSER, 1927, p. 5. - RoEWER, 1942, p. 902.-BONNET, 1955, p. 3201. - TIKADER, 1982, p. 135, figs. 251-255. -YAGINUMA, 1960, p. 63, pl. 27, fig. 156; 1986, p. 112, pl. 29, fig. 4. - MAтsumoto et al., 1976, p. 69, fig. 4. - ShinkAi \& TAKANO, 1984, p. 98. - PlATNICK, 1989, p. 354; 1993, p. 458- CHIKUNI, 1989, pp. 83, 217, fig. 66.

Caerostis cuspidata: WORKMAN, 1896, p. 26, pl. 26, figs. a-f.

Specimens examined. Holotype: 우 (young), Tharawaddy, Burma (=Myanmar), OATES leg. (BM1895.9.21.683).

Japanese specimens. 1 우, Musashimasuko, Itsukaichi-shi, Tokyo, 14-VIII-1995, M. BAN leg. (NSMT-Ar 3534); 2 egg sacs, Kotokuji, Itsukaichi-shi, Tokyo, 9-IX-1986, A. SHINKAI leg.; ljuv., Kyorin Univ., Hachiôji-shi, Tokyo, 30-V-1990, M. SADAMOTO leg.; 1juv., Zenpukuji park, Suginami, Tokyo, 16-VII-1995, M. SADAmOTO leg.; 1 万人, Hayama, Shiroyama-chô, Tukui-gun, Kanagawa Pref., 18-VIII-1996, M. BAN leg. (NSMT-Ar 3535); 1juv. Sagamihara, Sagamihara-shi, Kanagawa Pref., date unknown, S. OKAwA leg.; 1 juv., Ôma Shrine, Kumano-shi, Mie Pref., 25-VII-1993, A. TANIKAwA leg.; 1juv., same place and date, M. SADAmoto leg.; 1juv., Takada, Singu-shi, Wakayama Pref., 23-VII-1993, A. TANIKAWA leg.; 1 우, Shirahama-chô, Nishimuro-gun, Wakayama Pref., 22-VIII-1993, A. TANIKAWA leg. (NSMT-Ar 3536); 1juv., Yasu-chô, Kagami-gun, Kochi Pref., 5-VIII-1995, M. SADAMOTO leg.

Description (based on the Japanese specimens). Measurement (in $\mathrm{mm}$ ). Total length, 우 6.69-10.38, 이 1.92; carapace length 우 3.60-3.72, 이 1.05; width 우 3.24-3.40,

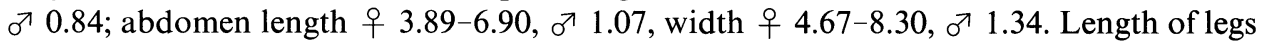
of 1 우 $1 \sigma^{7}$ from Tokyo and Kanagawa Pref. (NSMT-Ar 3536, 3535) as shown in Table 2 .

Table 2. Measurement of leg segments of Ordgarius sexspinosus (THORELL, 1894) (in $\mathrm{mm}$; 우/ 7 ).

\begin{tabular}{ccccccc}
\hline Leg & Tarsus & Metatarsus & Tibia & Patella & Femur & Total \\
\hline I & $0.82 / 0.35$ & $2.88 / 0.63$ & $2.84 / 0.62$ & $1.60 / 0.40$ & $3.40 / 0.82$ & $11.54 / 2.82$ \\
II & $0.80 / 0.32$ & $2.84 / 0.50$ & $2.68 / 0.53$ & $1.52 / 0.35$ & $3.48 / 0.76$ & $11.32 / 2.46$ \\
III & $0.64 / 0.26$ & $1.28 / 0.26$ & $1.46 / 0.32$ & $1.04 / 0.21$ & $2.28 / 0.53$ & $6.70 / 1.58$ \\
IV & $0.60 / 0.26$ & $1.82 / 0.27$ & $2.50 / 0.47$ & $1.26 / 0.28$ & $3.20 / 0.66$ & $9.38 / 1.94$ \\
\hline
\end{tabular}



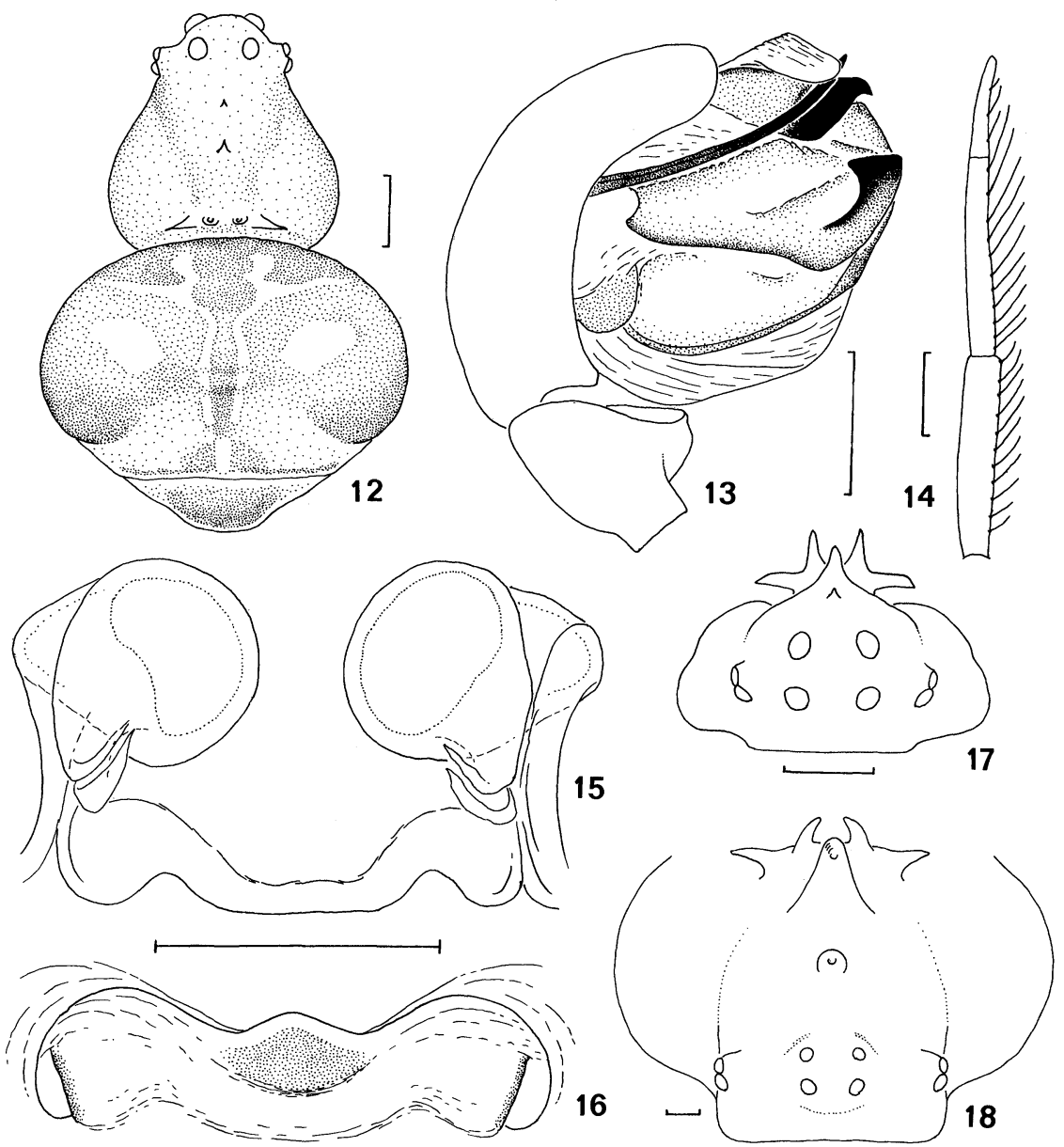

Figs. 12-18. Ordgarius sexspinosus (THORELL, 1894) (Female: NSMT-Ar 3536; male: NSMT-Ar 3535.) - 12. Male cephalothorax and abdomen, dorsal view. 13. Male left palp, mesal view. 14. Male left leg I, dorsal view. 15. Female genitalia, dorsal view. 16. Epigynum, ventral view. 17. Male cephalothorax, frontal view. 18. Female cephalothorax, frontal view. (Scales: $0.25 \mathrm{~mm}$.)

Female: Carapace length/width 1.09-1.11; with one small and one large curved projections on midline and four distinctive tubercles at the posterior end of cephalic region (Fig. 18). Median ocular area length/width $0.77-0.79$, anterior width/posterior width 1.09-1.21; median eyes situated on a gentle rise as well as lateral eyes (Fig. 18). Chelicera with two promarginal and one or two retromarginal teeth. Labium length/ width $0.64-0.70$. Sternum length/width 1.09-1.21. Length of leg I/length of carapace 3 . 10-3.21; metatarsi and tibiae of first and second legs prolaterally with a row of weak spines. Abdomen length/width 0.83; with rounded shoulder humps; and with two pairs of cones at the posterior end (Fig. 3). Female genitalia as in Figs. 15-16. Egg sac dark brown, encircled with a ling of points (Fig. 20). 


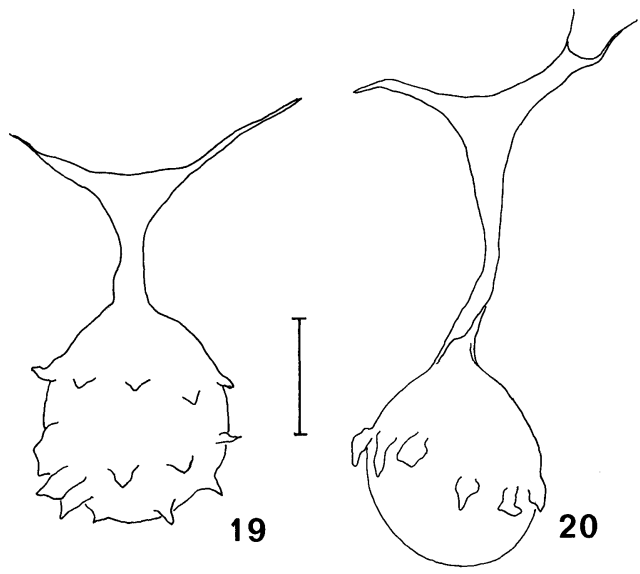

Fig. 19-20. Egg sacs. - 19. Ordgarius hobsoni (O. PICKARD-CAMBRIDGE, 1877). 20. Ordgarius sexspinosus (THORELL, 1894). (Scale: $5 \mathrm{~mm}$.)

Male: Carapace length/width 1.25; with one small and one large conical tubercles on midline and four distinctive tubercles at the posterior end of cephalic region (Fig. 17). Median ocular area length/width 1.25 , anterior width/posterior width 0.82 . Chelicera with three promarginal and one retromarginal teeth. Labium length/width 0.54 . Sternum length/width 1.03. Length of leg I/length of carapace 2.69 ; metatarsi and tibiae of first and second legs prolaterally with a row of spines (Fig. 14). Male palp (Fig. 13): embolus spiniform; terminal apophysis weekly sclerotized; conductor and median apophysis well sclerotized; patella without macroseta. Abdomen length/width 0.80; with a shoulder swelling (Fig. 12).

Coloration and markings in alcohol. Female. Cepharic region dark brown with transverse pale brown line, thoracic region pale brown. Abdomen pale brown with dark brown markings.

Male. Carapace dark brown with black marking. Abdomen dark brown mottled with blackish brown and pale brown, ventrally blackish brown with a pair of white spots.

Range. Japan, Burma (=Myanmar), Indonesia, India.

Remarks. I did not examine the epigynum of the holotype, because it was an immature specimen. The other features of the Japanese specimens agree exactly with those of the holotype.

The present species resembles Australian O. monstrosus KeYSERLING, 1886, in general appearance of female, and the shape of egg sac (Fig. 20; DAVIES, 1988, fig.36). The present species has conspicuous terminal apophysis as $O$. hobsoni. However, $O$. monstrosus has no terminal apophysis. The male of the present species has normal hair on the dorsum of the abdomen, but that of $O$. monstrosus has peculiar long hairs. Thus, these species seem to be closely related in females, but the relationship of these species based on the males is not so clear. Further examination is necessary to solve the problem. 


\begin{abstract}
摘要
日本産のイセキグモ属のクモ類について報告した. 神奈川県から得られた標本に基づ き, Ordgarius hobsoni (O. PICKARD-CAMBRIDGE, 1877) マメイタイセキグモおよび $O$. sexspinosus（THORELL，1894）ムツトゲイセキグモの雄を初めて記載した。
\end{abstract}

\title{
References
}

BonNET, P., 1955. Bibliographia Araneorum, 2(2), pp. 1-918. Toulouse.

ChIKUNI, Y., 1989. Pictorial Encyclopedia of Spiders in Japan. 308 pp. Kaiseisha, Tokyo. (In Japanese.)

DAviES, V. T., 1988. An illustated guide to the genera of orb-weaving spiders in Australia. Mem. Qd. Mus., 25: 273-332.

GertsCH, W. J., 1955. The North American bolas spiders of the genera Mastophora and Agatostichus. Bull. Amer. Mus. nat. Hist., 106: 225-254.

Keyserling, E., 1886. Die Arachniden Australiens. II, 33 \& 34 part., pp. 87-152. Nurnberg.

KISHIDA, K., 1933. [Ordgarius hobsoni, new to the Japanese fauna.] Zool. Mag., 45: 30. (In Japanese; not seen.)

Matsumoto, S., E. Shinkai \& H. OnO, 1976. Spiders. 194 pp. Gakushu-Kenkyusha, Tokyo. (In Japanese.)

PICKARD-CAMBRIDGE, O., 1877. On some new species of araneidea, with characters of two new genera, and some remarks on the families podopthalmids and dinopides. Proc. zool. Soc. London, 1877: 557 -578 , pls.LVI-LVII.

Platnick, N. I., 1989. Advances in Spider Taxonomy, 1981-1987. 673 pp. Manchester University Press, Manchester \& New York.

— 1993. Advances in Spider Taxonomy, 1988-1991. 846 pp. New York Entomological Society \& The American Museum of Natural History, New York.

Pocock, R.I., 1900. The Fauna of British India, including Ceylon and Burma. Arachnida. 279 pp. Taylor \& Francis, London.

ReIMOSER, E., 1927. Spinnen von Sumatras Ostkuste. Misc. zool. Sumatr., 13: 1-6.

RoEWER, C. F., 1942. Katalog der Araneae von 1758 bis 1940. Bd. 1. 1040 pp. Natura, Bremen.

SHINKAI, E., 1981. [A discovery of bolas spiders from Asia.] Atypus, (79): 32. (In Japanese.)

— \& S. TAKANO, 1984. A Field Guide to the Spider of Japan. 204 pp. Tokai Univ. Press., Tokyo. (In Japanese.)

Simon, E., 1895. Histoire Naturelle des Araigneés. Deuxieme edition, Tome 1, fascicule 3., pp. 7611084. Roret, Paris.

Stowe, M.K., 1986. Prey specialization in the araneidae. In W. A. SHEAR (ed.), Spiders-Webs, Behavior, and Evolution. pp. 101-131. Stanford Univ. Press, Stanford.

THORELl, T., 1894. Förteckning öfver Aråchnider fran Java och nargransande öar, insamlade af Carl AURIVILlIUS; jamte beskrifningar å några sydasiatiska och sydamerikanska spindlar. Bih. Svenska Vet.-Akad. Handl., 20: 1-63.

- 1895. Descriptive Catalogue of the Spiders of Burma. 406 pp. British Museum, London.

- 1898. Viaggiodi Leonardo FEA in Birmania e regioni vicine. LXXX. Secondo saggio sui Ragni birmani. II. Retitelariae et Orbitelariae. Ann. Mus. civ. stor. nat. Genova, 39: 271-378.

TIKADER, B.K., 1982. The Fauna of India. Spiders: Araneae. Vol.II. 536 pp. Zool. Surv. India, Calcutta.

WANG, J. F., Y. J. ZHANG \& F.J. LI, 1985. New report of some spiders from southern China. J. Hunan Normal Univ., 1985: 66-69.

Workman, T., 1896. Malaysian Spiders. Part 4-10. pp. 25-80, pls.25-80. Belfast.

YAGINUmA, T., 1941. [Some reports on spiders, (3).] Acta arachnol., 6:120-127. (In Japanese.)

- 1960. Spiders of Japan in Colour. 186 pp., 56pls. Hoikusha, Osaka. (In Japanese.) 
- 1986. Spiders of Japan in color (n. ed.). 305 pp. 64pls. Hoikusha, Osaka. (In Japanese.) 